\title{
Assessment of Universities' and Higher Education Centres' Preparedness for Successful Establishment of Enterprise Resource Planning Based on SWARA Method
}

\author{
Fatemeh Taghavi $^{1}$, Jurgita Antucheviciene ${ }^{2}$, Seyyed Aria Yaghobian ${ }^{3}$ \\ ${ }^{1,3}$ Contractor Company of Sarian-Sazeh-Gostar \\ No.5, Daya 8 av. Khazar Blvd, Sari, Mazandaran, Iran \\ E-mail.1Taghavi1368@yahoo.com,3Aria_yaghobian@yahoo.com \\ ${ }^{2}$ Vilnius Gediminas Technical University \\ Sauletekio av. 11, LT-10223, Vilnius, Lithuania \\ E-mail.jurgita.antucheviciene@vgtu.lt \\ cross $^{\text {ref }}$ http://dx.doi.org/10.5755/j01.ee.30.4.16379
}

Regarding existing pressures for effectiveness and performance improvement, there is a steep rise for the establishment of Enterprise Resource Planning (ERP). Unfortunately, failure rate for successful ERP establishment is high. Thereupon, evaluation of organizations' preparedness to ensure organizational capabilities aimed at reaching desired outcomes is of paramount importance. The current research is intended to suggest Step-wise Weight Assessment Ractio Analysis (SWARA) method and assess the preparedness of our case study, i.e. the University of Mazandaran, for successful ERP implementation. Related factors impacting on the accomplishment of the ERP system were identified from former studies and weighted according to a hierarchical structure using our suggested methodology. After receiving numerical results, the preparedness of the University of Mazandaran for successful ERP implementation was calculated when the final weights were determined. Results showed that motivations required for ERP establishment as well as processes and IT infrastructures are average, while the influencing cultural factors, protective factors, and capabilities of the organization are weak.

Keywords: Enterprise Resource Planning (ERP); Assessment of Preparedness; Critical Success Factors; Higher Education Centres; SWARA; University of Mazandaran.

\section{Introduction}

Enterprise Resource Planning System (ERP) is a configurable package that integrates and manages flow of information across all functional areas of an organization. ERP is an IT-based systematic solution that using an interconnected system quickly, accurately and in a qualitative manner provides managers of different levels of organization with organization's resources. Using ERP, they can properly manage organization's planning and operation processes. Causes of organizations' desire to accelerate and standardize the processes may include integration of operational information, integration of financial information, integration of customer order information, standardization and integration of human resources information, providing opportunity for organization. Today, given the many advantages of these systems, many organizations including universities are using these systems (Chen, 2011).

Universities are confronted with decreased governmental budgets as well as increased expectations of students and their parents to offer high-quality services with lowered expenses. Under such conditions, Enterprise Resource Planning (ERP) systems are proper solutions to help university deans to address such challenges (Juma et al., 2013). ERP system is a configurable software package that integrates and manages information flows at all functional areas (Chen, 2011). It is taken to universities to integrate and improve managerial and executive processes such as student registration, human resources systems, and financial processes (Von Hellens et al., 2005).
Despite such competitive advantages, there is still a high rate of failures for establishment of such systems as a main source of concern (Davenport, 1998). According to Al-Mashari (2000), approximately 70 percent of ERP projects fail to accomplish their pre-determined objectives. This indicates high levels of complexity of such systems compared to other systems, which necessitates basic organizational changes (Wang et al., 2008).

Therefore, feasibility studies and evaluations are to be well taken into account prior to implementation of such system. An assessment of such system is thus mandatory before ERP is implemented in order to have system implementations conducted based on existing realities and aligned with organizational capabilities and constraints (Shokri et al., 2011).

So far, to the best of our knowledge, no model-based research on key success criteria and factors in implementation of ERP system is presented in universities and higher education institutions and their preparedness to establish these systems is not evaluated. Since they are faced with a growing need to use such systems, so first of all this paper aims to introduce motives of universities and higher education institutions to apply ERP systems and then proposes a framework of key success factors for implementing these systems at universities and finally assess their preparedness before implementing such systems. This will help identify weaknesses and strengths of the centre and, in line with it, we can find a suitable platform for successful implementation of this system in the near future to minimize the likelihood of failure of the system. 
Steps and tools for this research are as follow: first, identifying factors affecting the ERP implementation (based on literature survey and expert survey); then, selecting an appropriate method for formal, objective (not subjective) evaluation; after that, selecting experts; and, finally, applying SWARA, receiving numerical results, and making conclusions.

\section{Literature Review}

A comprehensive management tool offered in a software package, i.e. ERP, is implemented in organizations to integrate all existing organizational systems and functions. ERP implementation is one of the most wide-ranging change activities that organizations have undergone in the last decade (Von Hellens et al., 2005).

ERP system includes the following departments: financial, accounting, supply chain and customer information, sales, distribution, production planning, material management and human resources management. This system includes software support modules where information between them flows and is shared in a central database (Clemmons \& Simon, 2001).

The system emerged in the late 1990s in manufacturing industry, where primary versions of applied software were being used for manufacturing resource planning (MRP) and computer integrated manufacturing (CIM). In fact, business organizations tended to use ERP systems to improve their business processes in order to reduce their automatic cost, to increase efficacy and to gain competitive advantage over their rivals (Nour \& Mouakket, 2011). Due to advantages of ERP system, many organizations have tended to use these systems. For example, an organization can take advantage of it through enhanced customer service and reduced production costs (Hendrickson 2010). Today many organizations around the world are using the system.

In educational institutes, however, ERP implementation has been challenging due to shortage of required experts and IT resources for its execution (Esteves \& Pastor, 2001). ERP is widely adopted in higher education institutes and its market has experienced a rapid rise in recent years (Harris et al. 2008). Related literature comprises motivations for ERP adoption in higher education centres and universities including updating systems, greater needs to flexibility and functionality, reengineering the business processes, integration of data and systems, risk avoidance and reduced maintenance (King, 2002; Oliver \& Romm, 2000), ERPrelated issues like organizational issues associated with decision-making process, management support, change management practices, project management issues, privacy and security issues, and impact of organizational culture (Von Hellens et al. 2005; Beekhuyzen, 2001).

ERP systems is initially designed to support ordinary organizational functions such as payroll issues, human resource management, materials management, accounting, etc. As ERP was extended into new aspects such as public segment, higher education, and service industries, new modules were added to fulfill industry- and operation-specific requirements (Pollock \& Cornford, 2004).

In case of higher education institutions, ERP systems can offer a different array of operational and university functions such as student enrolments (applications, fee calculation, short lists, etc.), course enrolments, student data management (attendance management, scientific degree information, etc.), course management (enrolments, course feedbacks), assets management (contracts, scholarships), library systems, graduates management, and research networks. Therefore, higher education presents special needs and challenges to the ERP execution. Complexity and broad scope of ERP execution have changed it into an important organizational change rather than a simple attempt to implement a technology (Pollock \& Cornford, 2004; Zornada \& Velkavrh, 2005). Universities are currently using the system around the world to benefit from its competitive advantages over other universities.

Despite its popularity, however, the failure rate of ERP implementation is still high. Thereupon, all organizations should pay enough attention to conscious decision-making. That is, they should through their in-depth studies to calculate exorbitant expenses, time of long-term projects, required human resources, organizational culture and so on to examine their preparedness for such a great change and avoid wasting of their financial/human resources and time (EshraghniaJahromi et al., 2005).

Critical success factors as well as those leading to failure and ineffective implementation of ERP in higher education centres have been discussed by some scholars. Rockhart (1997) defines critical success factors as a number of special areas which guarantee an organization's competitive performance if they are fully satisfactory. Identification of critical success factors helps recognition of required elements for a successful business operation (Hossein \& Shakir, 2001).

Although, identification of critical factors, which have critical role in success or failure of ERP implementation in an organization, is not sufficient. Having proper insight about the preparation level in order to manage the effort properly and to design strategies proper as critical factors in ERP implementation are of great importance. Organizations should, accordingly, assess and conduct feasibility studies before ERP implementations in order to align their organizational capabilities and constraints based on existing realities (Eshraghinia-Jahromi et al., 2005).

The current study is held for replying to three main questions:

RQ1. What is the final framework of critical success factors on successful ERP implementation?

RQ2. Which criteria and sub subcriteria are more important compared whit others in each category of final framework?

RQ3. What is the level of general preparedness for successful implementation of the system based on final factors in our case study?

\section{Methodology}

Since purpose of the research is investigating preparedness of universities and higher education centres for successful establishment of enterprise resource planning using key success criteria, so, first, we need a comprehensive list of appropriate criteria for this organization. Then we need to evaluate weight of these criteria, which is provided using SWARA method, and finally, we evaluate preparedness of an organization. To this purpose, we used comments of relevant experts at the intended university or higher education centre and a questionnaire. 
Generally, the present research includes three different phases to assess an organization's preparedness for ERP implementation (Figure 1):

Phase 1, in which an expert team is united. Then, the variables impacting on successful implementation of ERP systems are identified, after which questionnaires are distributed to experts to determine the most important qualitative and quantitative criteria. Figure2 exhibits the hierarchical diagram for affirmed variables.

Phase 2, in which factors and sub-factors are weighted in terms of experts' opinions using SWARA method.

Phase 3, in which sub-factors are assessed using Table 1 data and sub-factors' weight is multiplied by the assessed values. Table 1 is used to convert qualitative scales to quantitative scales according to the comments of the experts (Shokri et al., 2011). Then, the preparedness level of an organization to successfully implement ERP system in both general and separated manners is calculated.

Lingual Amounts to Measure Criteria

Table 1

\begin{tabular}{|c|c|}
\hline Lingual amounts & Assessment scale \\
\hline Very low & 0 \\
\hline Low & 25 \\
\hline Average & 50 \\
\hline High & 75 \\
\hline Very high & 100 \\
\hline
\end{tabular}

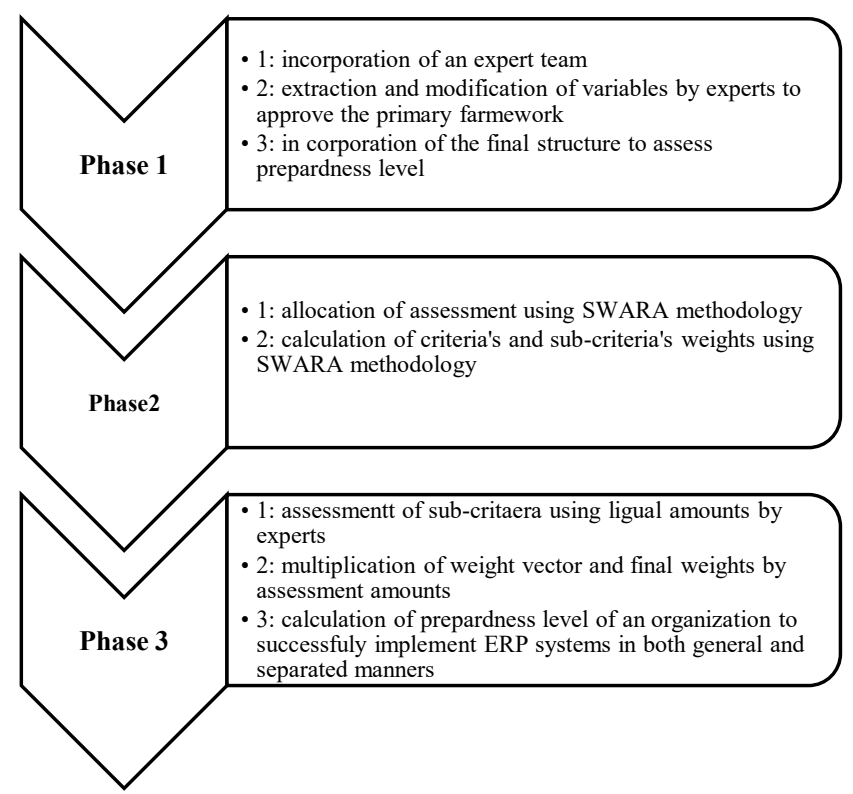

Figure 1. The Preparation Evaluation Process

\section{Phase 1}

The presented research aims to investigate effective criteria that influence on the success of ERP systems at organization, so, after extracting the criteria from the literature, we used experts' comments by using Delphi method to filter the criteria and present a suitable model. Finally, the selected criteria and sub-criteria were presented in Table 2 and as a framework in Figure 2.

\section{Phase 2}

\section{Step-wise Weight Assessment Ratio Analysis (SWARA) method}

Step-wise weight assessment ratio analysis (SWARA) was developed in 2010 (Kersuliene et al., 2010). The selection way was developed for the selection of rational dispute resolution (Kersuliene \& Turskis 2011).

In this way, experts have important role in evaluation and measurement. Experts' ability about importance of the ratio criteria relevant to the weight is the primary principle in this approach (Kersuliene et al., 2010).

Furthermore, this way is useful for consonance and data collecting from specialists. SWARA can be beneficial in some matters that preferences are recognized of their antecedent based on some circumstances (Hashemkhani-Zolfani et al., 2013). Moreover, this method is uncomplicated and specialists can simply work together.

The main advantage of this method in decision-making is that in some problems priorities are defined based on policies of companies or countries and there is no need for evaluation to rank criteria. SWARA can be useful for some issues with known priorities depending on a situation; and finally, SWARA is proposed in a certain environment of decisionmaking.

Priority of the main criteria based on policies of the studied organization in the current circumstances was found and evaluation of criteria rank is not done by the experts, therefore, the use of this method to determine weight of the criteria is a suitable method.

\section{The Computational Procedure of the SWARA Method}

Process of determining weight of criteria by using the SWARA method is based on following steps (Stanujkic et al. 2015; Kersuliene et al. 2010):

1. Determining criteria ranks: respondents arrange criteria according to rank (the most important criterion list as first, etc.)

2. Comparative importance of average value,

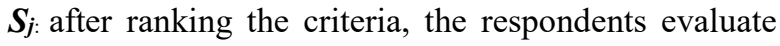
how much is $j+1$ criterion more important than $j$ criterion.

3. Determining the coefficient $\left(K_{j}\right)$ :

$K_{j}= \begin{cases}1 & J=1 \\ S_{j}+1 & J>1\end{cases}$

\section{Determining of recalculated weight $\left(q_{j}\right)$ :}

$q_{j}= \begin{cases}1 & J=1 \\ \frac{K_{j}-1}{K_{j}} & J>1\end{cases}$

\section{Determining of criteria importance $\left(W_{j}\right)$ :}

$$
\mathrm{w}_{\mathrm{j}}=\frac{q_{j}}{\sum_{\mathrm{j}=1}^{\mathrm{n}} q_{j}}
$$


Fatemeh Taghavi, Jurgita Antucheviciene, Seyyed Aria Yaghobian. Assessment of Universities' and Higher Education...

Factors Taken from Review of the Related Literature that Are Affecting on ERP Successful Implementation

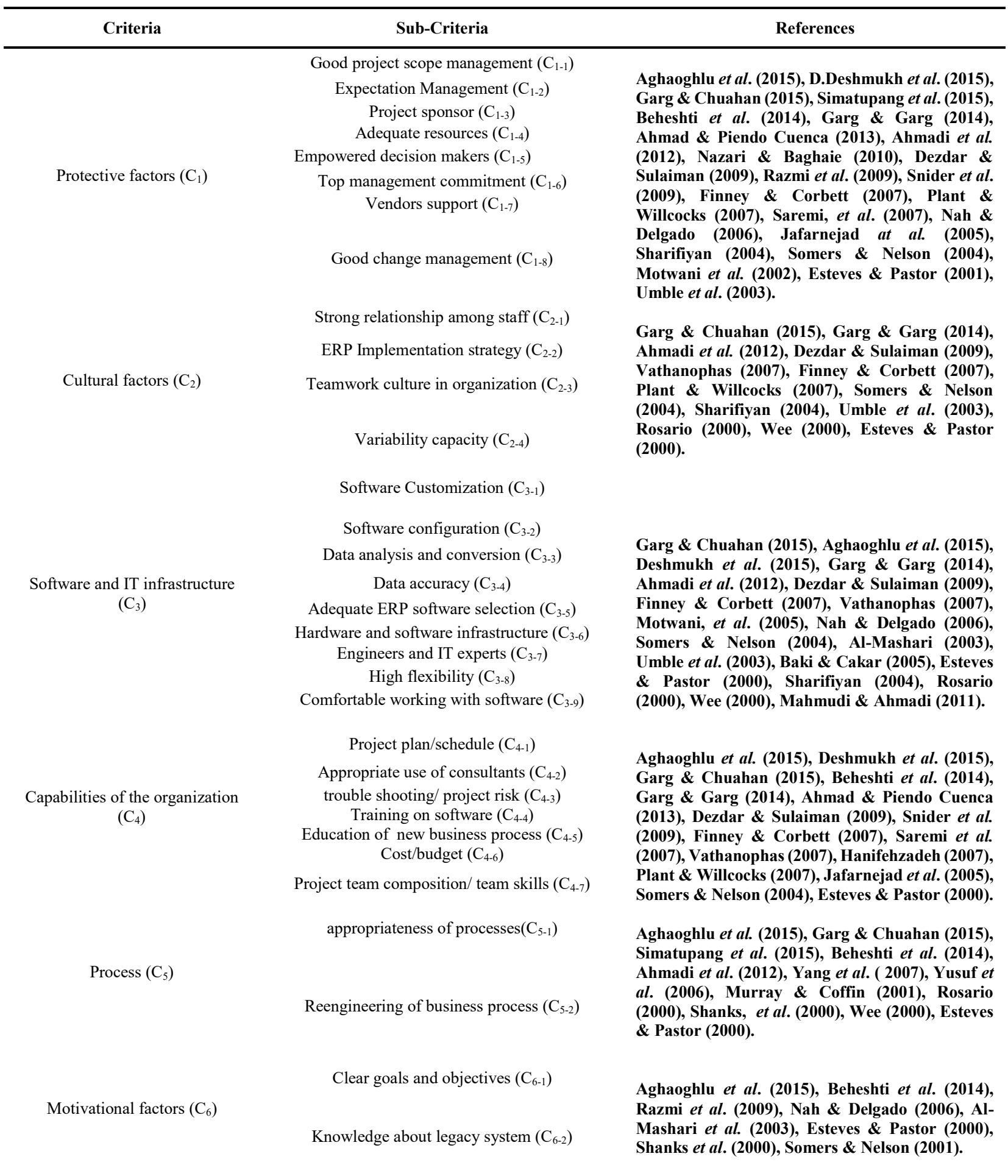




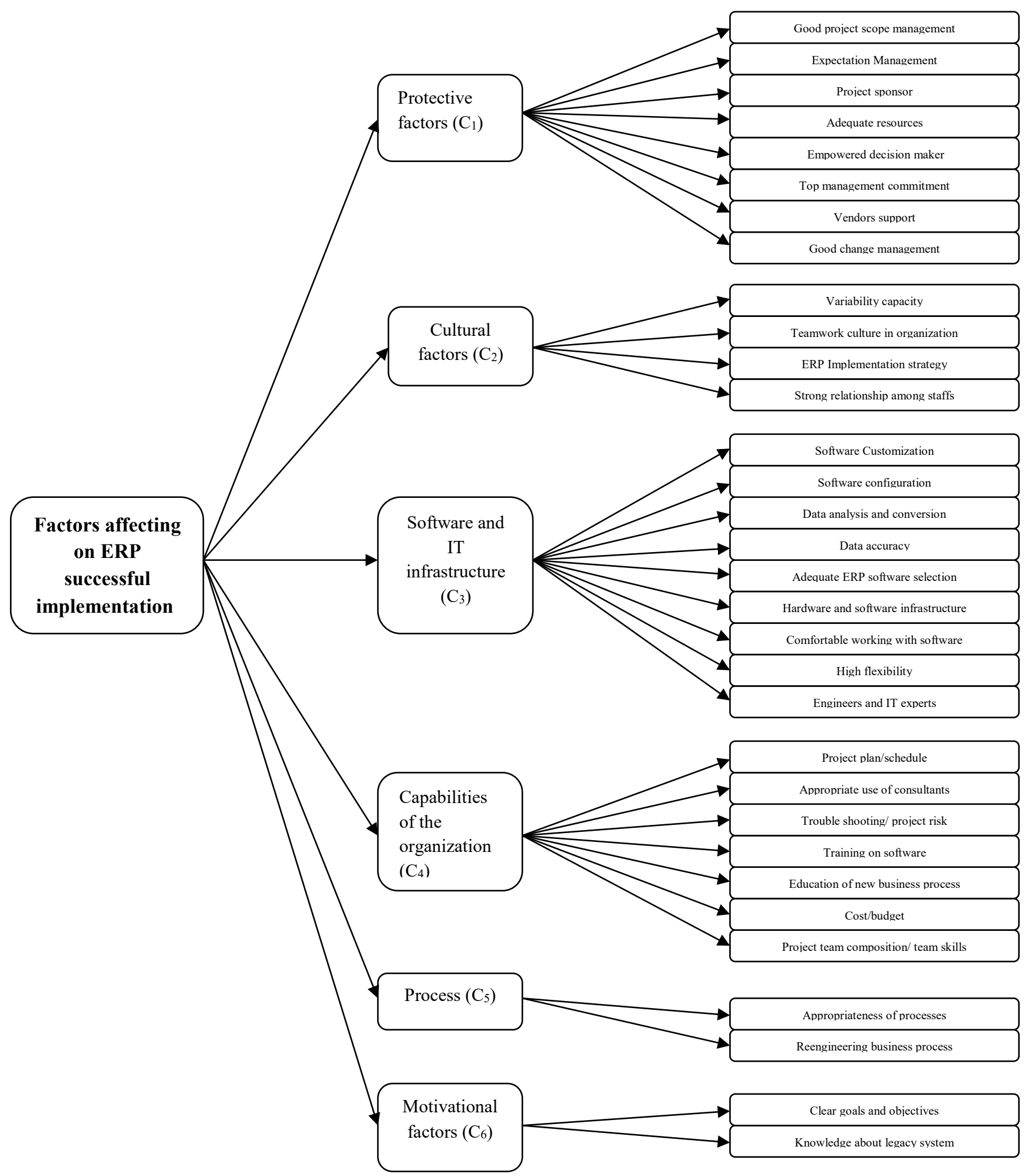

Figure 2. Final Structure of Approved Variables

Phase 3

When research variables were extracted and final structure was specified, data analysis method and expert team constituents were determined, the focus would, then, be on the numerical data.
The illustration of the current Phase is presented in Results section, using numerical data of a particular organization - University of Mazandaran. 
Fatemeh Taghavi, Jurgita Antucheviciene, Seyyed Aria Yaghobian. Assessment of Universities' and Higher Education...

\section{Results}

Experts' data for a case study of University of Mazandaran is presented in Table 3. Moreover, results of criteria's weights are displayed in the following Tables (45). Weight of sub-criteria is calculated in the same way and is presented in Table 6 .

Experts were, afterwards, asked to judge preparedness level of University of Mazandaran in terms of each of the components presented in Table 1. Since most sub-criteria of software and IT infrastructures are associated with ERP package, they cannot be used in preparedness assessment section, therefore, in which only two variables are considered and others are omitted. To do so, new weights of software and IT infrastructures sub-criteria are to be calculated regardless of the omitted sub-variables (Table 5).

Preparedness level of University of Mazandaran as separated by each factor as well as its general preparedness are shown in Table 6 and Table 7, respectively. In order to show more comfortably, the total results of Table 6 are indicated in Fig. 3.

Background Information of Experts

\begin{tabular}{|c|c|c|}
\hline Category & Classification & No. \\
\hline \multirow[t]{3}{*}{ Education } & Bachelor & $\overline{0}$ \\
\hline & Master & 3 \\
\hline & Ph.D. & 2 \\
\hline \multirow[t]{2}{*}{ Age } & $30-40$ & 4 \\
\hline & $40-50$ & 1 \\
\hline \multirow[t]{3}{*}{ Work experience } & $5-10$ & 2 \\
\hline & $10-15$ & 2 \\
\hline & $15-20$ & 1 \\
\hline \multirow[t]{2}{*}{ Sex } & Male & 5 \\
\hline & Female & 0 \\
\hline
\end{tabular}

Final Results of SWARA Method in weight Assessment Main Criteria

Table 4

\begin{tabular}{|c|c|c|c|c|}
\hline Criterion & $\begin{array}{c}\text { Comparative } \\
\text { importance of average } \\
\text { value } S_{j}\end{array}$ & $\begin{array}{c}\text { Coefficient } \\
K_{j}=S_{j}+1\end{array}$ & $\begin{array}{c}\begin{array}{c}\text { Recalculated } \\
\text { Weight } \\
q_{j}=\frac{X_{(j-1)}}{K_{j}}\end{array}\end{array}$ & $\mathrm{w}_{\mathrm{j}}=\frac{\begin{array}{c}\text { Weight } \\
\mathbf{q}_{\mathbf{j}}\end{array}}{\sum_{\mathrm{j}=\mathbf{1}}^{\mathbf{n}} \mathbf{q}_{\mathrm{j}}}$ \\
\hline$\overline{C_{1}}$ & 0 & 1 & 1 & 0.265 \\
\hline $\mathrm{C}_{6}$ & 0.3 & 1.3 & 0.769 & 0.203 \\
\hline $\mathrm{C}_{3}$ & 0 & 1 & 0.769 & 0.203 \\
\hline $\mathrm{C}_{4}$ & 0.475 & 1.475 & 0.521 & 0.14 \\
\hline $\mathrm{C}_{5}$ & 0.2 & 1.2 & 0.434 & 0.115 \\
\hline $\mathrm{C}_{2}$ & 0.55 & 1.55 & 0.28 & 0.074 \\
\hline
\end{tabular}

Final Results of SWARA Method in Weighting Criteria of Software and IT Infrastructure

\begin{tabular}{lccccc}
\hline Criterion & $\begin{array}{c}\text { Comparative } \\
\text { importance of } \\
\text { average value } \boldsymbol{S}_{\boldsymbol{j}}\end{array}$ & $\begin{array}{c}\text { Coefficient } \\
\boldsymbol{K}_{j}=\boldsymbol{S}_{j}+\mathbf{1}\end{array}$ & $\begin{array}{c}\text { Recalculated } \\
\text { Weight } \\
\boldsymbol{q}_{\boldsymbol{j}}=\frac{\boldsymbol{X}_{(\boldsymbol{j}-\mathbf{1})}}{\boldsymbol{K}_{\boldsymbol{j}}}\end{array}$ & $\begin{array}{c}\text { Weight } \\
\boldsymbol{W}_{\boldsymbol{j}}=\frac{\mathbf{q}_{\mathbf{j}}}{\sum_{\boldsymbol{j}=\mathbf{1}}^{\boldsymbol{n}} \mathbf{q}_{\mathbf{j}}}\end{array}$ & Total Weight \\
\hline $\mathrm{C}_{3-6}$ & 0 & 1 & 1 & 0.53 & $\mathbf{0 . 1 0 8}$ \\
$\mathrm{C}_{3-7}$ & 0.15 & 1.15 & 0.87 & 0.47 & $\mathbf{0 . 0 9 5}$ \\
\hline
\end{tabular}

Preparedness Assessment as Separated by Each Factor by Experts

\begin{tabular}{|c|c|c|c|c|c|}
\hline Criteria & Sub- Criteria & $\begin{array}{c}\text { Lingual } \\
\text { amounts } \\
\text { Average } \\
\end{array}$ & $\begin{array}{c}\text { Sub- Criteria } \\
\text { Weight }\end{array}$ & $\begin{array}{c}\text { Sub- Criteria } \\
\text { preparedness } \\
\text { level }\end{array}$ & $\begin{array}{c}\text { Criteria } \\
\text { preparedness } \\
\text { level }\end{array}$ \\
\hline \multirow{8}{*}{$\begin{array}{l}\text { Protective factors } \\
\qquad\left(\mathrm{C}_{1}\right)\end{array}$} & Good project scope management $\left(\mathrm{C}_{1-1}\right)$ & 50 & 0.213 & 10.65 & \multirow{8}{*}{28.382} \\
\hline & Expectation Management $\left(\mathrm{C}_{1-2}\right)$ & 37.5 & 0.08 & 3 & \\
\hline & Project sponsor $\left(\mathrm{C}_{1-3}\right)$ & 12.5 & 0.13 & 1.625 & \\
\hline & Adequate resources $\left(\mathrm{C}_{1-4}\right)$ & 50 & 0.105 & 5.25 & \\
\hline & Empowered decision makers $\left(\mathrm{C}_{1-5}\right)$ & 25 & 0.105 & 2.625 & \\
\hline & Top management commitment $\left(\mathrm{C}_{1-6}\right)$ & 25 & 0.157 & 3.92 & \\
\hline & Vendors support $\left(\mathrm{C}_{1-7}\right)$ & 0 & 0.105 & 0 & \\
\hline & Good change management $\left(\mathrm{C}_{1-8}\right)$ & 12.5 & 0.105 & 1.312 & \\
\hline \multirow{4}{*}{ Cultural factors $\left(\mathrm{C}_{2}\right)$} & Strong relationship among $\operatorname{staff}\left(\mathrm{C}_{2-1}\right)$ & 62.5 & 0.183 & 11.437 & \multirow{4}{*}{36.437} \\
\hline & ERP Implementation strategy $\left(\mathrm{C}_{2-2}\right)$ & 25 & 0.284 & 7.1 & \\
\hline & Teamwork culture in organization $\left(\mathrm{C}_{2-3}\right)$ & 50 & 0.183 & 9.15 & \\
\hline & Variability capacity $\left(\mathrm{C}_{2-4}\right)$ & 25 & 0.35 & 8.75 & \\
\hline
\end{tabular}


Inzinerine Ekonomika-Engineering Economics, 2019, 30(4), 496-506

\begin{tabular}{|c|c|c|c|c|}
\hline Criteria & Sub- Criteria & $\begin{array}{r}\text { Lingual } \\
\text { amounts } \\
\text { Average }\end{array}$ & $\begin{array}{l}\text { Sub- Criteria } \\
\text { Weight }\end{array}$ & $\begin{array}{c}\text { Sub- Crite } \\
\text { preparedn } \\
\text { level }\end{array}$ \\
\hline \multirow{2}{*}{$\begin{array}{c}\text { Motivational } \\
\text { factors }\left(\mathrm{C}_{6}\right)\end{array}$} & Clear goals and objectives $\left(\mathrm{C}_{6-1}\right)$ & 50 & 0.59 & 29.5 \\
\hline & Knowledge about legacy system $\left(\mathrm{C}_{6-2}\right)$ & 62.5 & 0.41 & 25.625 \\
\hline \multirow{7}{*}{$\begin{array}{l}\text { Capabilities of the } \\
\text { organization }\left(\mathrm{C}_{4}\right)\end{array}$} & Project plan/schedule $\left(\mathrm{C}_{4-1}\right)$ & 37.5 & 0.18 & 6.75 \\
\hline & Appropriate use of consultants $\left(\mathrm{C}_{4-2}\right)$ & 12.5 & 0.094 & 1.175 \\
\hline & trouble shooting/ project risk $\left(\mathrm{C}_{4-3}\right)$ & 37.5 & 0.124 & 4.65 \\
\hline & Training on software $\left(\mathrm{C}_{4-4}\right)$ & 50 & 0.11 & 5.5 \\
\hline & Education of new business process $\left(\mathrm{C}_{4-5}\right)$ & 25 & 0.075 & 1.875 \\
\hline & Cost/budget $\left(\mathrm{C}_{4-6}\right)$ & 37.5 & 0.265 & 9.937 \\
\hline & Project team composition/ team skills $\left(\mathrm{C}_{4-7}\right)$ & 37.5 & 0.152 & 5.7 \\
\hline \multirow{2}{*}{$\operatorname{Process}\left(\mathrm{C}_{5}\right)$} & appropriateness of processes $\left(\mathrm{C}_{5-1}\right)$ & 50 & 0.45 & 22.5 \\
\hline & Reengineering business process $\left(\mathrm{C}_{5-2}\right)$ & 62.5 & 0.55 & 34.375 \\
\hline \multirow{2}{*}{$\begin{array}{l}\text { Software and IT } \\
\text { infrastructure }\left(C_{3}\right)\end{array}$} & Hardware and software infrastructure $\left(\mathrm{C}_{3-1}\right)$ & 62.5 & 0.53 & 33.125 \\
\hline & Engineers and IT experts $\left(\mathrm{C}_{3-2}\right)$ & 50 & 0.47 & 23.5 \\
\hline
\end{tabular}

Figure 3. University of Mazandaran's Preparedness Level as Separated by Each Critical Factor

General Preparedness Assessment by Experts

\begin{tabular}{|c|c|c|c|}
\hline Criteria and Sub- Criteria & Total Weight & Lingual amounts Average & General preparedness \\
\hline Protective factors & 0.265 & & \\
\hline Good project scope management & 0.056 & 50 & 2.8 \\
\hline Expectation Management & 0.021 & 37.5 & 0.787 \\
\hline Project sponsor & 0.034 & 12.5 & 0.425 \\
\hline Adequate resources & 0.028 & 50 & 1.4 \\
\hline Empowered decision makers & 0.028 & 25 & 0.7 \\
\hline Top management commitment & 0.042 & 25 & 1.05 \\
\hline Vendors support & 0.028 & 0 & $\mathbf{0}$ \\
\hline Good change management & 0.028 & 12.5 & 0.35 \\
\hline Cultural factors & 0.074 & & \\
\hline Strong relationship among staff & 0.0135 & 62.5 & 0.844 \\
\hline ERP Implementation strategy & 0.021 & 25 & 0.525 \\
\hline Teamwork culture in organization & 0.0135 & 50 & 0.675 \\
\hline Variability capacity & 0.026 & 25 & 0.65 \\
\hline Capabilities of the organization & 0.138 & & \\
\hline Project plan/schedule & 0.0252 & 37.5 & 0.945 \\
\hline Appropriate use of consultants & 0.013 & 12.5 & 0.162 \\
\hline trouble shooting/ project risk & 0.0172 & 37.5 & 0.645 \\
\hline Training on software & 0.0154 & 50 & 0.77 \\
\hline Education of new business process & 0.011 & 25 & 0.275 \\
\hline Cost/budget & 0.037 & 37.5 & 1.387 \\
\hline $\begin{array}{l}\text { Project team composition/ team } \\
\text { skills }\end{array}$ & 0.0212 & 37.5 & 0.795 \\
\hline Process & 0.115 & & \\
\hline appropriateness of processes & 0.0517 & 50 & 2.585 \\
\hline Reengineering business process & 0.0633 & 62.5 & 3.956 \\
\hline
\end{tabular}


Fatemeh Taghavi, Jurgita Antucheviciene, Seyyed Aria Yaghobian. Assessment of Universities' and Higher Education ...

\begin{tabular}{lccc}
\hline \multicolumn{1}{c}{ Criteria and Sub- Criteria } & Total Weight & Lingual amounts Average & General preparedness \\
\hline Motivational factors & $\mathbf{0 . 2 0 3}$ & 50 & $\mathbf{6}$ \\
\hline Clear goals and objectives & 0.120 & 62.5 & $\mathbf{5 . 1 8 7}$ \\
\hline Knowledge about legacy system & 0.083 & & $\mathbf{6 . 7 5}$ \\
\hline Software and IT infrastructure & $\mathbf{0 . 2 0 3}$ & 62.5 & $\mathbf{4 . 7 5}$ \\
\hline $\begin{array}{l}\text { Hardware and software } \\
\text { infrastructure }\end{array}$ & 0.108 & 50 & $\mathbf{4 4 . 4 1 3}$ \\
\hline Engineers and IT experts & 0.095 & & \\
\hline Sum & $\mathbf{1}$ & & \\
\hline
\end{tabular}

\section{Conclusions}

Since the failure rate of implementing ERP systems in organizations is still high, so, investigation of preparedness level is a preliminary study to determine a project's successfulness probability before it is emerged in the real world. This process ensures achievement of desired objectives by organizational capabilities in order to allow making decision about either completion or rejection of a project. Successful assessment of ERP systems and the way to achieve them are important issues, which have been addressed by many researchers. This is obvious that identification of factors which lead to a project's success or failure is very important in ensuring of the organization's preparedness level. The main input of the current study to ERP and at the same time to enterprise management is the suggestion of the framework applying SWARA method for weighting of decision criteria.

Many organizations in the world today tend to use ERP systems so that thorough its implementation to gain competitive advantages over other organizations. In the meantime, universities are no exception. This research besides expressing motivations of universities and higher education institutions for establishing this system was also intended to present an appropriate framework of such critical success factors for University of Mazandaran, followed by assessing its preparedness level. After different variables were extracted and their effectiveness/ ineffectiveness was tested by experts, a final structure for assessment was achieved, whereby criteria and sub-criteria were assigned weight using SWARA method. This is a relatively simple method in decision-making process, in which trainings and experiences of experts play a significant role.

As a result protective factors were determined as the most important criteria, and after that Software and IT infrastructure as well as Motivational factors have the same importance, and lower priority criteria are Capabilities of the organization, Process and Cultural factors.

After obtaining general preparedness level of University of Mazandaran by using weights of criteria and sub-criteria also the scores which experts have pointed to those, results demonstrate that motivations required to establishment of this system, processes and IT infrastructures are average, while influencing cultural factors, protective factors and capabilities of the

\section{References}

Aghaoghlu, M., Yurtkoru, E. S., \& Ekmekci, A. K. (2015). The effect of ERP implementation CSFs on business performance: an empirical study on users' perception. Procedia- Social and Behavioral Science, 210, 35-42. https://doi.org/10.1016/j.sbspro.2015.11.326 organization are much feeble and call for serious improvements.

As shown in Table 7, preparedness level of our case study is generally 44.413, which is a low-to-average level. Preparedness in strong relationship among staffs, appropriateness of processes, and knowledge about legacy system as well as hardware/software infrastructures are at a suitable level. Despite high significance of protective factors, project's sponsor, expectations management, empowered decision makers, commitment and supports by top management, vendors' supports, and effective organizational change management, they are at a week level. In addition, preparedness level of University of Mazandaran regarding the following variables was assessed to be low: ERP implementation strategy and variability capacity of cultural factors, project plan/schedule, troubleshooting/ project risk, appropriate use of consultants and training of new business processes, cost/budget, and team skills. Other items are average.

In studies already done by (Beheshti et al. 2015; Mahmoud \& Ahmadi, 2011; Nour \& Mouakket, 2011; Aghaoghlu, 2014), we saw more that researchers are trying to provide frameworks or appropriate models for successful implementation of ERP system in manufacturing and distribution companies or in state or private organizations, which is done by identifying and prioritizing key factors of success implementation of ERP. Also, the topic of evaluating preparedness of organizations for successful implementation of the system is considered in several studies, but examining all these topics together at universities and higher education centres are not taken into consideration. Additionally, to do this research at the study centre, we were faced by the limited number of experts who were completely familiar with the subject, which may limit to some extent generalization of the research results.

Regarding high importance of ERP implementation and increasing need for it in universities and higher education centres, relevant officials are recommended to present this framework to their experts in order to enable them to test and then achieve an inclusive framework of variables that should be taken into consideration before ERP systems are implemented.

As a future research plan, the authors are going to achieve an extensible and comprehensive final framework of critical success factors for ERP implementation by the help of related experts of all universities and higher education centres of the country. 
Ahmad, M. M., \& Cuenca, R. P. (2013). Critical success factors for ERP implementation in SMEs. Robotics and Computer-Integrated Manufacturing, 29, 104-111. https://doi.org/10.1016/j.rcim.2012.04.019

Ahmadi, A. A., Karimzadehgan-Moghadam, D., Vahdat, D., \& Khalil-Samani, V. (2012). A pattern for assessment of ERP system using FANP. Ninth industries engineering international conference, Khaje Nasir-e Toosi Industrial University.

Al-Mashari, M. (2000). Construct of process change management in ERP context: a focus on SAP R/3. AMCIS 2000 Proceedings, 113.

Baki, B., \& Cakar, K. (2005). Determining the ERP package-selecting criteria: the case of Turkish manufacturing companies. Business Process Management Journal, 11(1), 75-86. https://doi.org/10.1108/14637150510578746

Beekhuyzen, J. (2001). Organizational culture and enterprise resource planning (ERP) systems implementation. Griffith University.

Beheshti, H. M, K. Blaylock, B., A. Henderson, D., \& G. Lollar, J. (2014). Selection and critical success factors in successful ERP implementation. International Business Journal Incorporating Journal of Global Competitiveness, 24(4), 357-375. https://doi.org/10.1108/CR-10-2013-0082

Bingi, P. K., Sharma, M., \& K. Godla, J. (2013). Critical issues affecting an ERP implementation. Information Systems Management, 16(3), 7-14. https://doi.org/10.1201/1078/43197.16.3.19990601/31310.2

Chen, I. J. (2011). Planning for ERP systems: Analysis and future trend. Business Process Management Journal, 7(5), 374-386. https://doi.org/10.1108/14637150110406768

Clemmons, S., \& Simon, S. J. (2001). Control and coordination in global ERP configuration. Business Process Management Journal, 7(3), 205-215. https://doi.org/10.1108/14637150110392665

Davenport, T. (1998). Putting the enterprise into the enterprise system, Harvard Business Review, 76 (4), 121 -132.

Deshmukh, P. D, Thampi, G. T., \& Kalamkar, V. R. (2015). Investigation of quality benefits of ERP implementation in Indian SMEs. Procedia Computer Science, 49, 220-228. https://doi.org/10.1016/j.procs.2015.04.247

Dezdar, S., \& Sulaiman, A. (2009). Successful enterprise resource planning implementation: taxonomy of critical factors. Industrial Management \& Data Systems, 109(8), 1037-1052. https://doi.org/10.1108/02635570910991283

Eshraghinia-Jahromi, A., Javdani-Tabrizinejad, M., \& Hejazi, S. F. (2005). ERPII feasibility study in Iran. Third International Management Conference, December 20-22, Tehran. http://www.civilica.com/Paper-IRIMC03IRIMC03_183.html

Esteves, J., \& Pastor, J. (2001). Enterprise resource planning system research: An annotated bibliography. Communications of the Association for Information Systems, 7(8), 1-52. http://aisel.aisnet.org/cais/vol7/iss1/8?utm source=aisel.aisnet.org\%2Fcais\%2Fvol7\%2Fiss 1\%2F8\&utm_medium=PDF\&utm_campaign=PDF CoverPages.

Finney, S., \& Corbett, M. (2007). ERP implementation: a compilation and analysis of critical success factors. Business Process Management Journal, 13(3), 329-347. https://doi.org/10.1108/14637150710752272

Garg, P., \& Chauhan, A. (2015), Factors affecting the ERP implementation in Indian retail sector. International Journal of Bench Marketing, 22, 1315-1340. https://doi.org/10.1108/BIJ-11-2013-0104

Garg, P., \& Garg, A. (2014). Factors influencing ERP implementation in retail sector: an empirical study from India. Journal of Enterprise Information Management, 27, 424-448. https://doi.org/10.1108/JEIM-06-2012-0028

Hanafizadeh, P., \& Zare-Ravasan, A. (2011). Investigation of organizational preparedness for ERP implementation based on the McKinsey7S framework. Kar-o-Jame'e Social, Economic, Scientific, and Cultural Journal, 136, $22-40$.

Harris, M., Lowendahl, J. M., \& Zastrocky, M. (2008). Magic quadrant for higher education administrative suites, Gartner Industry Research.

Hashemkhani-Zolfani, S., Aghdaie, M. H., Drakhti, A., MorshedVarzandeh, M. H., \& Zavadskas, E. K. (2013). Decision making on business issues with foresight perspective; an application of new hybrid MCDM model in shopping mall locating. Journal of Expert Systems with Applications, 40, 7111-7121. https://doi.org/10.1016/j.eswa. 2013.06.040

Hashemkhani-Zolfani, S., Esfahani, M. H., Bitarafan, M., Zavadskas, E.K., \& Lale_Arefi, SH. (2013). Developing a new hybrid MCDM method for selection of the optimal alternative of mechanical longitudinal ventilation of tunnel pollutants during automobile accidents. Transport, 28(1), 89-96. https://doi.org/10.3846/16484142.2013.782567

Hendrickson, D. (2010). Getting more out of ERP. EAI Journal, December, 24-27.

Hossain, L., \& Shakir, M. (2001). Stakeholder involvement framework for understanding the decision-making process of ERP selection in New Zealand. Journal of Decision Systems, 1(10), 11-27. https://doi.org/10.3166/jds.10.11-27

Jafarnrjad, A., Banijamali, S. M., \& Hagh-Parast, M. (2005). Presence of a framework to assess Persian organization's preparedness level for ERP implementation. Third International Management Conference, Tehran: Ariana Research Group, December 20-22. http://www.civilica.com/Paper-IRIMC03-IRIMC03_047.html 
Fatemeh Taghavi, Jurgita Antucheviciene, Seyyed Aria Yaghobian. Assessment of Universities' and Higher Education...

Juma, S., Makokha, A., \& Musiega, D. (2013). Implementation of enterprise resource planning in Kenyan public universities: A case of Masinde -Muliro University of Science and Technology. Research Journal of Finance and Accounting, 4(6), 26-34.

Kersuliene, V., \& Turskis, Z. (2011). Integrated fuzzy multiple criteria decision making model for architect selection. Technological and Economic Development of Economy, 17(4), 645-666. https://doi.org/10.3846/20294913.20 11.635718

Kersuliene, V., Zavadskas, E. K., \& Turskis, Z. (2010). Selection of rational dispute resolution method by applying new Step- Wise Weight Assessment Ratio Analysis (SWARA). Journal of Business Economics and Management, 11(2), 243-258. https://doi.org/10.3846/jbem.2010.12

King, P. (2002). The promise and performance of enterprise systems in higher education respondent Summary. ECAR Respondent Summary, http://net.educause.edu/ir/library/pdf/ecar_so/ers/ers0204/EKF0204.pdf (retrieved April 20, 2012).

Mahmoudi, J., \& Ahmadi, F. (2011). Determination of ERP critical success factors in Iran's governmental organizations. New Economics and Commerce Journal, 13, 67-88.

Motwani, J., Subramanian, R., \& Gopalakrishna, P. (2005). Critical factors for successful ERP implementation. Computers in Industry, 56, 529-544. https://doi.org/10.1016/j.compind.2005.02.005

Murry, M., \& Coffin, G. (2001). A case study analysis of factors for success in ERP systems implementations. AMCIS 2001 Proceedings, 196, 1012-1018.

Nah, F. F. H., \& Delgado, S. (2006). Critical success factors for enterprise resource planning implementation and upgrade. Journal of Computer Information Systems, 46(5), 99. https://doi.org/10.1080/08874417.2006.11645928

Nazari, M., \& Baghaei, S. (2010). An inclusive look into ERP critical success factors. Management Age Journal, 16 \& $17,98-103$.

Nour, M. A., \& Mouakket, S. (2011) A Classification Framework of Critical Success Factors for ERP Systems Implementation: A Multi-Stakeholder Perspective. International Journal of Enterprise Information Systems, 7(1) pp.56-71. https://doi.org/10.4018/jeis.2011010104

Oliver, D., \& Romm, C. (2000). ERP systems: the route to adoption. AMCIS 2000 Proceedings, 209, $1039-1044$.

Plant, R., \& Willcoks, L. (2007). Critical success factors in international ERP implementations: a case research approach. Journal of Computer Information Systems, 47(3), 60.

Pollock, N., \& Cornford, J. (2004). ERP Systems and the University as a "unique" organization. Information Technology and People, 17(1), 31-52. https://doi.org/10.1108/09593840410522161

Razmi, J., Sangari, M. S., \& Ghodsi, R. (2009). Developing a practical framework for ERP preparedness using fuzzy analytic network process. Advances in Engineering Software, 40, 1168-1178. https://doi.org/10.1016/j.adve ngsoft.2009.05.002

Rockart, J. F. (1979). Chief executives define their own data needs. Harvard Business Review, 57(2), 81-93.

Rosario, J. G. (2000). On the leading edge: critical success factors in ERP implementation projects. Business World, 17(May), 15-29.

Saremi, M., Mousakhani, M., \& Abedini, M. (2006). Extraction and assessment of the indices related to vehicle manufacturing industry to implement ERP. Management Science Journal, 77, 47-60.

Shanks, G., Parr, A., Hu, B., \& Corbitt, B. (2000). Differences in critical success factors in ERP systems implementation in Australia and China: a cultural analysis. ECIS 2000 Proceedings, 53, 537-544.

Sharifiyan, N. (2004). Examination of ERP systems providing process and its implementation problems (case study: Hamkaran system group). Industrial Management Master Thesis, University of Tehran.

Shokri, R., Khazaki, H. R. \& Rabbani, Y. (2011). ERP pre-implementation: a model. Case study: Bandar-Abbas oil refinery Co. Management and HR in Oil Industry Scientific and Research Quarterly, 15, 103-136.

Simatupang, T. M., Putro, U. S., \& Hermawan, P. (2015). Actors' interaction in the ERP implementation literature. Business Process Management Journal, 21(2), 222-249. https://doi.org/10.1108/BPMJ-11-2013-0142

Snider, B., Da Silveria, G. J. C., \& Balakrishan, J. (2009). ERP implementation in SMEs: analysis of five Canadian cases. International Journal of Operations \& Production Management, 29(1). 4-29. https://doi.org/10.1108/01443 570910925343

Somers, T. M., \& Nelson, K. G. (2004). A taxonomy of players and activities across the ERP project life cycle. Information \& Management, 41(3), 257-278. https://doi.org/10.1016/S0378-7206(03)00023-5 
Stanujkic, D., Karabasevic, D., Zavadskas, E. K. (2015), A framework for selection of a packaging design based on SWARA method. Inzinerine Ekonomika-Engineering Economics, 26(2), 181-187. https://doi.org/10.57 55/j01.ee.26.2.8820

Tarhini, A., Ammar, H., \& Tarhini, T. (2015). Analysis of the critical success factors for enterprise resource planning implementation from stakeholders' perspective: A systematic review. International Business Research, 8(4), 25. https://doi.org/10.5539/ibr.v8n4p25

Umble, E. J., Haft, R. R., \& Umble, M. M. (2003). Enterprise resource planning: implementation procedures and success factors. European Journal of Operational Research, 146(2), 241-257. https://doi.org/10.1016/S0377-2217(02) 00547-7

Vathanophas, V. (2007). Business process approach towards an inter-organizational enterprise system. Business Process Management Journal, 13(3), 433-450. https://doi.org/10.1108/14637150710752335

Von Hellens, L., Nielsen, S., \& Beekhuyzen, J. (Eds.). (2005). Qualitative case studies on implementation of enterprise wide systems. Igi Global. https://doi.org/10.4018/978-1-59140-447-7

Wang, E. T. G., Shih, S. P., \& Jiang, J. J. (2008). The consistency among facilitating factors and ERP implementation success: a holistic view of fit. Journal of Systems and Software, 81(9), 1609-1621. https://doi.org/10.10 16/j.jss.2007.11.722

Wee, S. (2000). Juggling toward ERP success: keep key success factors high. Retrieved from http://www.erpnews.com/ erpnews/erp904/02get.html.

Yang, J., Wu, C., \& Tsai, C. (2007). Selection of an ERP system for construction firm in Taiwan: a case study. Automation in Construction, 16(6), 787-796. https://doi.org/10.1016/j.autcon.2007.02.001

Yusef, Y., Gunasekaran, A., \& Wu, C. (2006). Implementation of enterprise resource planning in China. Technovation, 26(12), 1324-1336. https://doi.org/10.1016/j.technovation.2005.12.003

Zornada, L., \& Velkavrh, T. B. (2005). Implementing ERP systems in higher education institutions. Conference of Information Technology Interfaces, June 20-23, 307-313. https://doi.org/10.1109/ITI.2005.1491143

The article has been reviewed.

Received in October 2016; accepted in October 2019. 